\title{
Application of Multiliteration Models For Improving Student Speaking Skill of Elementary School
}

\author{
Sigit Vebrianto Susilo ${ }^{1}$, Krisna Anggraeni ${ }^{2}$, Reza Rachmadtullah ${ }^{2}$ \\ \{sigit.vebrianto@gmail.com ${ }^{1}$, krisnaanggraeni24@gmail.com ${ }^{2}$, rezarachmadtullaheza@gmail.com\}
}

Universitas Majalengka, Jln. K.H. Abdul Halim No. 103 Majalengka, Jawa Barat, Indonesia ${ }^{1,2}$ Universitas PGRI Adi Buana, Jl. Dukuh Menanggal XII, Surabaya 60234 Jawa Timur, Indonesia ${ }^{3}$

\begin{abstract}
Indonesian language learning in elementary schools should be done with the right model. However, in elementary education Heubeulisuk I, teachers still do learning that is only teacher-centered so that students in Indonesian language learning tend to be passive and in particular their speaking skills are low. The application of multiliteration models is carried out as an alternative to improve speaking skills. This research is a classroom action research in class V elementary education Negeri Heubeulisuk I Majalengka, as many as 20 students. This study aims to find out: (1) the application of multiliteration models 2) speaking skills (3) speaking skills improvement for fifth grade students of Heubeulisuk I Elementary School Majalengka. This classroom action research was carried out using John Elliot's model, which was carried out with 3 cycles and 3 cycle actions. The results showed that: (1) The application of multiliteration learning model was successfully implemented well (2) The speaking skills of students achieve $80 \%$ classical completeness or achieve the target in cycle III of action 1 which obtained 85\% classical completeness, (3) Application of proven Multiliteration Model can improve the speaking skills of fifth grade students at Heubeulisuk Public Elementary School, it can be seen from the pre-cycle results that continue to increase until the third cycle and reach the target in the third cycle of action 1 which obtains classical completeness by $85 \%$.
\end{abstract}

Keywords: Multiliteration Model, Speaking Skill

\section{Introduction}

Changes in the way of communicating cannot be separated from the concept of literacy (read-write) in the global era [1]. Traditional view suggests that the text is a printed symbol. The digital era with its various service products is an effective way to change the way of communicating with all people throughout the world [2]. In line with the digital era, education in the 21 st century has at least four important competencies that must be mastered by students, among them areconcept comprehension competencies, critical thinking competencies, competencies collaboration and communication [3], [4]. Therefore, the skills that must be mastered in order to create multiliteration learning are the ability to read high comprehension, good writing skills, speaking skills, and mastering skills in various digital media [5]. Thus, the goal of Indonesian language learning is directed to achieve several goals that must be possessed by students namely language skills, language attitudes, knowledge of linguistic knowledge of Indonesian language, self awareness of the importance of literary work for selfdevelopment, and students' positive attitudes towards literary work [6]. 
21st century skills are (1) life and career skills, (2) learning and innovation skills, and (3) Information media and technology skills. These three skills are summarized in a scheme called the century of knowledge skills rainbow $21 / 21^{\text {st }}$ century knowledge-skills rainbow [7].

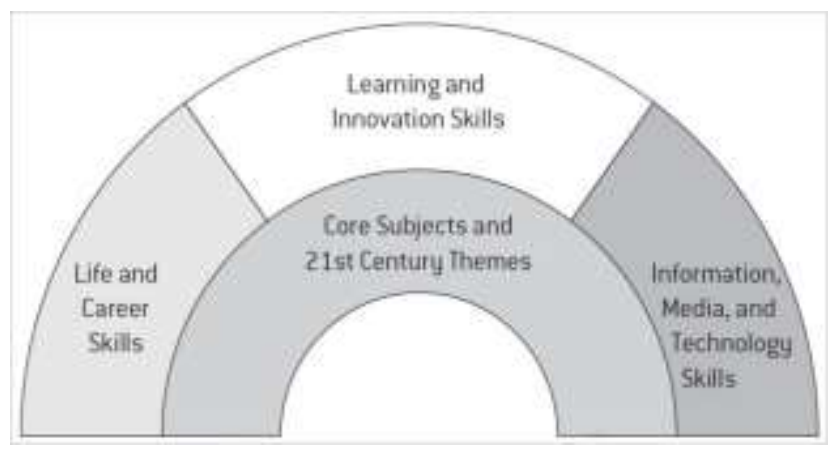

Figure 1. Rainbow of 21st Century Skills Knowledge

Education in the 21st century should be able to form human beings to be human beings who are critical in intellectual, creative in thought, ethical in relationships, and character in life [6], [8]. This means that education in the 21 st century spurred humanity as the main actor in life in the world for charity in various fields. The younger generation of the future must be able to no longer work with muscles, but must be able to with the brain, changing the paradigm that working is not only enough to have one skill, but multi-skills / multidimensional. On this basis, his education is capable of being the frontline in fostering and shaping young Indonesian people to have multidimensional abilities and skills [9].

Based on preliminary studies the ability to speak at elementary education Heubeulisuk class $\mathrm{V}$ is still far from ideal conditions in learning. Understanding of Indonesian language material, especially in expressing ideas that are owned by students or speaking both asked by the teacher and to appear in front of the class. Based on the data obtained, there were only 8 students who successfully achieved the KKM (Minimum Completion Criteria) of 22 students, meaning that only $36.40 \%$ reached the KKM and 14 students or $63.60 \%$ who had not reached the KKM with KKM 75, this was due to lack of low language skills of elementary school students.

The main purpose of talking is to communicate. Communication is the sending and receiving of messages or news between two or more people so that the message in question can be understood. [10]. Speaking is basically an interactive process of communication that emphasizes on aspects of language including listening, speaking, reading and writing skills [11]. Speaking skills are also able to give birth to future generations who are cultured because they are accustomed and trained to communicate with other parties according to the material and speech situation when speaking. Speaking skills have an important role in the effort to give birth to future generations who are intelligent, creative, critical and cultured [12]. Speaking skills are a type of skill that is very important to communicate. With speaking skills one can convey (1) various kinds of information, (2) willingness and desire (3) disclosure of various feelings [13].

multiliteration concept development in education was never apart from art-based pedagogical concept, multiple ways of knowing, and multipelintelegensi for students [6]. Multiliteration learning model is a learning model that aims to develop and optimize students' critical thinking skills, students' conceptual understanding, students' creative thinking, and 
collaborative and communicative among students [14]. In line with this, multiliteration is also believed to be able to develop high-level creativity as an important skill for students. With multiliteration learning, students can optimize language skills so that the competencies of critical thinking, conceptual, collaborative, and communicative thinking arise and produce products in realizing learning situations and are useful in creating conditions of inquiry-based learning and integrative thematic learning in elementary students [6].

\section{Method}

Method used in this study is a Class Action Research method. The procedure of classroom action research is (1) planning (2) action, (3) observation, and (4) reflection [15]. The data obtained are sourced from the work process of speaking, observation, interviews, field notes, and documentation. The model used is J. Elliot's [15].

\section{Result and Discussion}

\subsection{Result}

Based on evaluation, observation and testing of fifth grade students through classroom action research, obtained as shown in Table 1. Student learning outcomes in cycles 1, 2 and 3 are shown in graph 1 as follows.

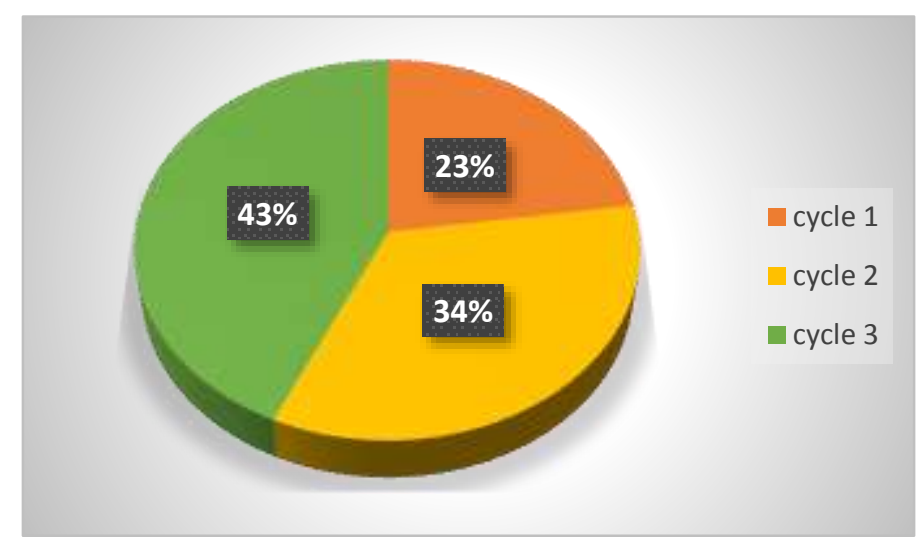

Fig.1. Graph of Speaking Skills Test Results

Based on the graph above the classical completeness is achieved in the action of 1 III cycle, where students who have speaking skills above the criteria are sufficient that is good and very good has reached $95 \%$ of all students or as many as 17 students from all students, namely 20 and continue up to cycle III action 3 .

\subsection{Discussion}


Increasing the process of speaking skills in cycle I to cycle II increased by $75 \%$, then an increase from cycle II to cycle III was $95 \%$. Whereas for the results of speaking skills in cycle I to cycle II increased by $25 \%$ and continued with an increase from cycle II to cycle III increased by $20 \%$. Based on the description above, it can be concluded that the multiliteration learning model in Indonesian subjects can improve the speaking skills of fifth grade students at Heubeulisuk Elementary School. The results of the research are in line with the theory including that multiliteration models have the advantage of developing high-level creativity, training students' critical inquiry, increasing thinking ability and high-level understanding of thinking, multiliteration models are able to develop high-level creativity with learning that focuses on the use of multiliteration concepts including improving skills speak [6].

In addition, there are also complementary objectives of the multuliteration model including the development of student clarity on cultural diversity, social phenomena and global demands, the formation of life and career skills in students, the formation of student independence in learning, work, and work and the development of students' skills in learning, work, and work, and reflective thinking [16].The next theory suggests that the skills mastered in multiliteration learning are the ability to read high comprehension, good writing skills, speaking skills, and mastery of various digital media [6].

\section{Conclusion}

The application of the Multiliteration Model is proven to improve the speaking skills of fifth grade students at Heubeulisuk Public Elementary School, it can be seen from the prasiklus results that continue to increase until the third cycle and reach the target in the third cycle of action 1 which has a classical completeness of $85 \%$.

\section{References}

[1] L. B. Sari E.S, Suryaman M, "Model Multiliterasi Dalam Perkuliahan Pendidikan Bahasa Dan Sastra Indonesia," Litera, vol. 12, no. 2, 2013.

[2] C. Borsheim, K. Merritt, and D. Reed, "Beyond Technology for Technology's Sake: Advancing Multiliteracies in the Twenty-First Century," Clear. House A J. Educ. Strateg. Issues Ideas, vol. 82, no. 2, pp. 87-90, Nov. 2008.

[3] R. Rachmadtullah, Z. Ms, and M. S. Sumantri, "Development of computer - based interactive multimedia : study on learning in elementary education," Int. J. Eng. Technol., vol. 7, no. 4, pp. 2035-2038, 2018.

[4] L. S. F. Graham, Meadow Sherril, Sheila Benson, "A Springboard Rather Than a Bridge: Diving into Multimodal Literacy," English J., vol. 200, no. 153, pp. 93-97, 2010.

[5] B. T. Williams, “"Tomorrow Will Not be Like Today': Literacy and Identity in a World of Multiliteracies," J. Adolesc. Adult Lit., vol. 51, no. 8, pp. 682-686, May 2008.

[6] Y. Abidin, Pembelajaran Multiliterasi: Sebuah Jawaban Atas Tantangan Pendidikan Abad Ke21. Bandung: Rafika Aditama, 2015.

[7] C. Morocco, Supported literacy for adolescents: transforming teaching and content learning for the twentyfirst century. San Fransisco: JosseyBass A Wiley Imprint., 2010.

[8] Y. Abidin, Desain Sistem Pembelajaran Dalam Konteks Kurikulum 2013, Cetakan I. Bandung: Refika Aditama, 2014.

[9] M. S. Sumantri, A. W. Prayuningtyas, R. Rachmadtullah, and I. Magdalena, "The Roles of Teacher-Training Programs and Student Teachers' Self-Regulation in Developing Competence in Teaching Science," Adv. Sci. Lett., vol. 24, no. 10, pp. 7077-7081, Oct. 2018. 
[10] N. S, "Peningkatan Keterampilan Berbicara melalui Metode Bercerita Siswa Kelas III SD Negeri 1 Beringin Jaya Kecamatan Bumi Raya Kabupaten Morowali,” J. Kreat. Tadulako, vol. 2, no. 4, 2015.

[11] J. Yan, H. H. Goh, and H. X. Zhou, "Improving the Teaching of Chinese Speaking of Young Students from English-Speaking Families: Teacher's Professional Development," in Teaching Chinese Language in Singapore, Singapore: Springer Singapore, 2018, pp. 65-82.

[12] X. Daming, "English Language Teaching in East Asia Today: Changing Policies and Practices," Asian Englishes, vol. 6, no. 1, pp. 86-88, Jun. 2003.

[13] G. Keraf, Diksi dan Gaya Bahasa. Jakarta: Gramedia Pustaka Utama.

[14] Y. H. Azizah I N, Abidin Y, "Penggunan Model Multiliterasi Untuk Meningkatkan Kemampuan Menulis Karangan Eksposisi:," J. Antropol., vol. 3, no. 2, 2015.

[15] M. G. E, Action research,A guide for the teacher researcher 2nd. New Jersey: Merrill Prentice Hall, 2011.

[16] Febriana, "Implementasi Model Multiliterasi Pada Proses Pembelajaran Membaca Pemahaman Siswa Kelas IV Sekolah Dasar,” Junal Sekol., vol. 1, no. 2, 2017. 